\title{
Immunity in Hong Kong for Kleptocrats and Human Rights Violators
}

\author{
Simon N. M. Young*
}

The Court of Final Appeal's decision in Congo v FG Hemisphere has signifcant human rights implications beyond the borders of Hong Kong. Current and former heads of state wanted for crimes against humanity or grand corruption can rest assured that the Hong Kong court will not strip them of immunity from prosecution like the House of Lords did in the case concerning General Augusto Pinochet. Former leaders need only worry that the immunity has not been waived by the new rulers. Stolen state assets are also safe in Hong Kong, subject only to waiver of immunity and United Nations Security Council sanctions which China has allowed Hong Kong to implement and enforce.

\section{Introduction}

Most would shudder at the suggestion that the courts and executive in Hong Kong must speak with one voice on matters of human rights. Yet, could this be the implication of Congo $v$ FG Hemisphere in holding that Hong Kong's law and policy on state immunity must be the same as that of the Chinese mainland? ${ }^{1}$ Although Congo was not a criminal or human rights case, it is now the leading authority on how claims of immunity made in Hong Kong proceedings are to be handled. ${ }^{2}$ Does Congo send a message to the world that deposed dictators and their assets can find sanctuary in Hong Kong, free from the accountability mechanisms of international justice? In short, this comment submits that the answer is a qualified yes, though the exceptions are very limited. It is no coincidence that the word immunity is but a letter shy of the word impunity.

* Associate Professor and Director, Centre for Comparative and Public Law, Faculty of Law, The University of Hong Kong. I thank C.L. Lim for his comments on an earlier draft.

1 Democratic Republic of the Congo v FG Hemisphere Associates LLC [2011] 4 HKC 151 (hereinafter "Congo").

2 International law recognises different types of immunities. Congo was concerned with state immunity or the immunity of a state. Other immunities include sovereign immunity which is the immunity of a head of state or former head of state, and diplomatic immunity relating to the immunities of diplomats and diplomatic missions. The scope of and exceptions to each immunity may differ. See generally Hazel Fox, The Law of State Immunity, 2nd edn (Oxford: Oxford University Press, 2008). 


\section{Hong Kong, an Attractive Safe Haven}

The idea of Hong Kong harbouring current and former heads of state wanted for international crimes is not merely hypothetical. Less than a month after the Congo judgment, China's President, Hu Jintao, welcomed Sudan's president, Omar al-Bashir, in Beijing, notwithstanding the warrants for the latter's arrest issued by the International Criminal Court (ICC) and the international criticisms of the visit. ${ }^{3}$ ICC arrest warrants were issued in 2009 and 2010 for the Sudanese president, one alleging three counts of genocide and the other alleging several counts of war crimes and crimes against humanity, relating to the atrocities in the Darfur region. ${ }^{4}$ Immunity is not an issue for the ICC as the Rome Statute expressly removes this bar to prosecution. ${ }^{5}$ China is not a signatory to the Rome Statute and has several reservations about the ICC. ${ }^{6}$

Zimbabwe's President, Robert Mugabe, and his family are regular visitors to Hong Kong, partly because his daughter was a student in a local university. ${ }^{7}$ The widely reported incidences of alleged assaults on foreign journalists by Mugabe's wife and security guards, and the subsequent controversy over the non-prosecution of these individuals due to diplomatic immunity and other reasons, did not deter the Mugabes from returning. ${ }^{8}$

Public attention to politically exposed persons and their financial dealings has increased significantly with the entry into force of the United Nations Convention Against Corruption (UNCAC). ${ }^{9}$ Parties to the UNCAC are bound not only to take steps to prevent corruption, particularly corruption on a massive scale (also known as grand corruption

3 Stephanie Nebehay, "U.N. rights boss raps China for not arresting Bashir", Reuters, 30 June 2011.

4 "Pre-Trial Chamber I issues a second warrant of arrest against Omar Al Bashir for counts of genocide", ICC Press release, ICC-CPI-20100712-PR557, 12 July 2010.

5 Rome Statute of the International Criminal Court, 17 July 1998, UN Doc A/CONF.183/9*, and corrections in CN.577.1998 TREATIES-8 (Annex) and CN.357.1999 TREATIES-14 (Annex), reprinted in 37 ILM 999 (1998) (hereinafter "Rome Statute"), Art 27.

6 For China's position on the ICC, see Bing Bing Jia, "China and the International Criminal Court: Current Situation” (2006) 10 Singapore Yearbook of International Law 87.

7 Barclay Crawford \& Liz Heron, "Armed with immunity, Mrs Mugabe returns", South China Morning Post, 17 Oct 2009.

8 Legislative Council Secretariat, "Fact sheet: A summary of local press reports on the incidents concerning the wife and daughter of the President of the Republic of Zimbabwe from Jan 2009 to June 2009", FC29/08-09, 9 July 2009, accessible at www.legco.gov.hk; Niall Fraser, "Reviled at home but relaxed in Hong Kong, Robert Mugabe stocks up on shoes and suits", South China Morning Post, 15 Aug 2010; C. L. Lim \& Roda Mushkat, "The Hong Kong S.A.R. and External Affairs" in Johannes Chan \& C. L. Lim (eds), The Law of the Hong Kong Constitution (Hong Kong: Sweet \& Maxwell, 2011, forthcoming) (hereinafter "Lim \& Mushkat").

9 United Nations Convention Against Corruption, GA Resolution 58/4 of 31 Oct 2003, entering into force on 14 Dec 2005 (hereinafter "UNCAC"). 
or kleptocracy), but also to provide assistance and co-operation in the international recovery of stolen assets. ${ }^{10}$ When corrupt regimes and leaders fall, it is common now to see the in-coming authority take legal action to try to recover the ill-gotten gains of the old regime. The Arab Spring of late 2010 saw the fall of the Tunisian and Egyptian leaders, followed almost immediately by asset freezes of property owned by the deposed leaders and their families. ${ }^{11}$ If, hypothetically, regime change were to occur in Zimbabwe someday, international attention will certainly turn to Hong Kong where, as reported in 2009, the Mugabe family was said to own a luxury home worth more than 45 million HKD. ${ }^{12}$ When asked about the Mugabe property, the Chinese government's attitude to the issue at the time was revealed in this reply from the Foreign Ministry's spokesperson: "Hong Kong is a free port, and even Falun Gong practitioners can buy a property there, am I right?"13

\section{Pinochet and Hong Kong}

To illustrate the Hong Kong approach to state immunity, consider how the CFA would decide the Pinochet case if the same circumstances were to arise in Hong Kong. ${ }^{14}$ General Augusto Pinochet, while in London for medical treatment, was the subject of an arrest and later extradition request issued by a Spanish magistrate. ${ }^{15}$ Exercising universal jurisdiction, the Spanish request alleged that General Pinochet from 1973 (when he took power in Chile after leading a military coup) to 1990 commanded a criminal organisation that carried out illegal detentions, kidnapping, torture followed by death, forced displacement and disappearances of thousands of people of different nationalities (including Spanish). ${ }^{16}$ The litigation that ensued in the English courts is notorious

10 UNCAC, Ch 2 (preventive measures), Ch 4 (international cooperation), Ch 5 (asset recovery).

11 "Switzerland freezes assets of Zine al-Abidine Ben Ali and Laurent Gbagbo", The Guardian, 19 Jan 2011; Phillip Inman \& Rajeev Syal, "Egyptian officials' assets to be traced by Serious Organised Crime Agency", The Guardian, 15 Feb 2011; "Switzerland identifies \$1bn worth of dictators' assets", The Guardian, 3 May 2011.

12 Malcolm Moore, "Zimbabwe: Robert Mugabe 'buys $£ 4 \mathrm{~m}$ apartment in Hong Kong'”, The Telegraph, 15 Feb 2009.

13 Albert Wong, Raymond Li \& Ambrose Leung, "Why can't Mugabe buy a flat in HK, asks Beijing”, South China Morning Post, 17 Feb 2009.

14 R v Bow Street Metropolitan Stipendiary Magistrate Exp Pinochet Ugarte (No 3) [2000] 1 AC 147 (HL) (hereinafter "Pinochet"). See also Reed Brody \& Michael Ratner (eds), The Pinochet Papers: The Case of Augusto Pinochet in Spain and Britain (The Hague: Kluwer Law International, 2000) (hereinafter "Pinochet Papers").

15 Reed Brody, "The Case of Augusto Pinochet" in Pinochet Papers, ibid., 7-9.

16 "The Spanish Extradition Request" in Pinochet Papers, ibid., 209-210. 
and well-documented. ${ }^{17}$ Ultimately in the second hearing in the House of Lords, there were two issues that had to be decided. The first issue was whether the crimes alleged against General Pinochet were "extradition crimes" within the Extradition Act 1989, and the second issue was whether General Pinochet was entitled to immunity as a former head of state in relation to such crimes? ${ }^{18}$

On the first issue, the House of Lords held that, as a result of the principle of double criminality, General Pinochet could only be extradited to face charges in relation to torture occurring on or after 29 September 1988, which is when torture outside the United Kingdom became a domestic offence. ${ }^{19}$ On the second issue, the Law Lords held in a majority of six to one that General Pinochet was not entitled to immunity. Although the reasons given varied, Lord Browne-Wilkinson, in his speech presenting the judgment to the full House of Lords, stated that the "basic proposition common to all" the judgments in the majority was that:

\begin{abstract}
"torture is an international crime over which international law and the parties to the Torture Convention have given universal jurisdiction to all courts wherever the torture occurs. A former head of state cannot show that to commit an international crime is to perform a function which international law protects by giving immunity." 20
\end{abstract}

A subsequent House of Lords decision, Jones $v$ Ministry of Interior for the Kingdom of Saudi Arabia, however confirmed that the immunity will apply to a civil claim brought against a State and its agents in respect of torture committed on the territory of that State. ${ }^{21}$

Pinochet would be handled very differently if its facts arose in Hong Kong. The first obvious difference is that a Spanish extradition request may go unanswered because Spain and Hong Kong have no bilateral extradition agreement. However Hong Kong is bound by several important international criminal law and human rights treaties, including the UNCAC and Convention Against Torture but not the Rome Statute, and the extradition obligations within these multilateral

17 See generally Pinochet Papers, ibid.

18 "Speeches to the House of Lords, 24 Mar 1999 (Summary of Report of the Appellate Committee)" in Pinochet Papers, ibid., 252-254.

19 Ibid.

20 Ibid., 253-254.

21 Jones v Ministry of Interior Al-Mamlaka Al-Arabiya AS Sudiya (the Kingdom of Saudi Arabia) [2006] UKHL 26 (hereinafter "Jones"). 
instruments could require a request from Spain or another state party to be acted upon.

With respect to the first Pinochet issue, the Hong Kong court would approach the matter like most other common law courts. The issue concerns extradition law which is an aspect of foreign affairs that the Central People's Government has authorised Hong Kong to conduct on its own. ${ }^{22}$ Applying common law principles the court would determine how the double criminality rule contained in the Fugitive Offenders Ordinance applies to the circumstances of the case. ${ }^{23}$ One factual difference is that torture outside of Hong Kong did not become a domestic offence until 21 January 1993 when the Crimes (Torture) Ordinance came into force. $^{24}$ If the Hong Kong court follows the Pinochet holding it would mean there was no extraditable offence because General Pinochet relinquished power in 1990, three years before torture became a domestic offence.

A stark difference appears in how the Hong Kong court approaches the second issue. Taking first the approach of the dissenting judges in Congo, they would see the task as ascertaining the post-1997 common law position in Hong Kong of immunity for former heads of state in relation to torture committed while serving as a head of state. ${ }^{25}$ The approach would have regard to Chinese policy but not submit to it. ${ }^{26}$ Lord BrowneWilkinson's statement in Pinochet of the common law position would be persuasive, although not controlling. His Lordship held that at common law a former head of state loses immunity, ratione personae, on leaving office and enjoys only immunities, ratione materiae, meaning subjectmatter immunity covering only official acts done whilst head of state. ${ }^{27}$ If the court also accepts the proposition that the commission of an international crime such as torture (and perhaps also grand corruption) could not conceivably be regarded as an official function of a head of state, then the immunity will be pierced. ${ }^{28}$ The Chinese policy being a relevant and distinct consideration may contribute to a different result, but ultimately the minority's approach is one that allows for a richer more cosmopolitan

22 See Basic Law, Arts 96 \& 153; See n 8 above.

23 The double criminality rule is contained in s 2(2) of the Fugitive Offenders Ordinance (Cap 503).

24 Crimes (Torture) Ordinance (Cap 427), originally Ord No 11 of 1993; Crimes (Torture) Ordinance (11 of 1993) (Commencement) Notice 1993, L.N. 17 of 1993.

25 Congo, paras 84, 523.

26 Congo, paras $124,127 \& 524$.

27 Pinochet, 202.

28 There is support for this in the Pinochet judgments of Lord Browne-Wilkinson (p 205), Lord Hope (p 247), Lord Hutton (p 264), Lord Millet (p 277), and Lord Phillips (p 292). 
legal debate that draws upon comparative developments in the common law and international law.

By contrast the majority's approach is narrow, affording limited scope for judicial analysis. No Art 158 reference will be needed because the CFA's comprehensive reference in Congo settles the approach to be adopted. According to this approach, the Hong Kong courts and Central Authorities must speak with one voice on state immunity law and policy. The task then is to ascertain the relevant Chinese policy and apply it as Hong Kong law to the circumstances of the case. The issue of the immunity of a former head of state was not considered in Congo, thus necessitating the relevant position to be established either by the Art 19 fact of state certificate procedure or, via the less formal procedure endorsed in Congo, an official letter from the Office of the Commissioner of the Ministry of Foreign Affairs of China setting out the relevant position. ${ }^{29}$ Indeed the practical reality may well be that once the Chinese policy of upholding the immunity is determined, the matter will not reach the courts because the executive will have declined to take action. ${ }^{30}$

Does it matter that the prohibition against torture is a customary international law norm of jus cogens status? The Law Lords in Jones, citing the International Court of Justice's decision in Democratic Republic of the Congo v Belgium, ${ }^{31}$ did not believe the jus cogens character of the norm weakened the claim to immunity because immunity is a procedural doctrine that did not necessarily result in the breach of the jus cogens norm. ${ }^{32}$ But more relevant to Hong Kong's Congo case is whether the jus cogens character of the norm requires that the Hong Kong courts have greater autonomy to decide the question of immunity. Unfortunately there is nothing in the Congo judgments that would seem to allow for such an exception.

\section{Congo and the Immunity of Former Heads of State}

The majority's watertight approach to state immunity can be summarised as follows. First, it is "a State's prerogative to decide on the scope of the immunity it is prepared to confer on other States and in particular, whether to recognize further exceptions to absolute immunity" [emphasis

29 Basic Law, Art 19(3); Congo, para 363.

30 As was the case with the non-prosecution of Grace Mugabe for assault due to a claim of diplomatic immunity, see $n 8$ above.

31 Arrest Warrant of 11 Apr 2000 (Democratic Republic of the Congo v Belgium), Judgment, ICJ Reports 2002, p 3.

32 Jones, para 24. 
added]. ${ }^{33}$ Arguably Pinochet is not a case concerning an exception to absolute immunity, but one can hardly deny that it concerns the scope or width of the immunity doctrine; the question being the scope of the immunity enjoyed by current and former heads of state. ${ }^{34}$ Second, under the Basic Law, this prerogative is exercised exclusively by the Central Authorities, and Hong Kong has no authority to decide its own state immunity law and policy. ${ }^{35}$ Third, to allow Hong Kong to adopt a possibly divergent state immunity policy risks causing embarrassment and prejudice to China in its conduct of foreign affairs. ${ }^{36}$ It would be inconsistent for the Hong Kong courts to reach the same result as in Pinochet while the Chinese policy is to accord full immunity ratione personae to former heads of state. Fourth, Hong Kong courts apply a common law of immunity that is necessarily adapted and modified to conform with Hong Kong's status as a local administrative region of China. ${ }^{37}$ In practice, this means executive declarations of facts of state stating China's immunity policy control the common law position to be applied.

The majority reserved only minimal authority for judicial decisionmaking. First, it is for courts to determine the legal consequences that flow from the facts of state and particularly how the common law is to be modified in accordance with Hong Kong's status. ${ }^{38}$ But the practical reality is that the declarations of facts of state will be drafted by lawyers to leave the court little room to drift from the declaration in the adaptation process. Second, courts can decide issues related to waiver of state immunity. ${ }^{39}$ The majority also noted that courts may decide other legal issues but gave no hints as to what those issues might be. ${ }^{40}$ Waiver would seem to be the only way for a Hong Kong court to seize jurisdiction in a Pinochet-type case. The waiver would need to come from the state and not the former sovereign. ${ }^{41}$ But the majority's requirement of an unequivocal express waiver from the state at the time the court's jurisdiction is invoked leaves no room to argue that ratification of the Convention Against Torture or breach of a jus cogens norm are enough to constitute a valid waiver. ${ }^{42}$ It may however be that Congo's stringent waiver test

33 Congo, para 231.

34 Note that the certified question before the House of Lords in Pinochet was "the proper interpretation and scope of the immunity enjoyed by a former head of state from arrest and extradition proceedings in the United Kingdom in respect of acts committed while he was head of state" (p 152).

35 Congo, paras 324-331.

36 Congo, paras $269 \& 290$.

37 Congo, paras 297, 313, $323 \& 336$.

38 Congo, para 297.

39 Congo, para 298.

40 Ibid.

41 Pinochet, 205.

42 Congo, para 392; Pinochet, 267 (Lord Saville). 
should not apply to immunity claims made by a former head of state; a less exacting standard should be applied by the court where the common purpose is to avoid impunity for an international crime.

There is no reason to believe that the Chinese policy will be anything less than absolute immunity ratione personae for former heads of state. Chinese concerns with the ICC, particularly its jurisdiction over nationals of non-state parties, and the exercise of universal jurisdiction by some countries are well documented. ${ }^{43}$ These concerns are likely heightened by law suits that have been brought in the United States and Spain against former Chinese President Jiang Zemin. ${ }^{44}$

\section{Immunity and Asset Freezes}

As with extradition requests and prosecution, immunity which has not been waived will preclude almost all actions to freeze and seize the assets of serving and former heads of state, whether by criminal or civil processes. Issues will arise if the asset is not held in the name of the leader/ former leader but in the name of a family member, associate or company. Most of these issues will concern not the scope of the immunity doctrine but rather the application of the doctrine and, as such, can be left to the courts to decide.

A particularly interesting scenario is where the imprimatur of the asset freeze is from the United Nations Security Council acting under Chapter VII of the United Nations Charter. A recent case in point is the action taken in early 2011 against Libya and its current head of state, Muammar Qadhafi. In February and March, the Security Council passed two resolutions under Chapter VII requiring member states to impose an arms embargo, travel ban, assets freeze and other measures against the Libyan leader and his supporters. ${ }^{45}$ On 30 June 2011, regulations to implement these two resolutions were gazetted in Hong Kong. ${ }^{46}$

Could proceedings under the regulations against Qadhafi and/or his property be halted on grounds of immunity? What makes this scenario unique is that China could have vetoed the Security Council resolutions.

43 See n 6 above; Xue Hanqin, "Chinese Observations on International Law" (2007) 6 Chinese Journal of International Law 83, 91-93.

44 Plaintiffs A, B, C, D, E, F v Jiang Zemin, 282 F.Supp.2d 875 (2003) (DC); Mugambi Jouet, "Spain's Expanded Universal Jurisdiction to Prosecute Human Rights Abuses in Latin America, China, and Beyond" (2007) 35 Georgia Journal of International and Comparative Law 495.

45 UN Security Council Resolution 1970, UN Doc S/RES/1970 (2011), 26 Feb 2011; UN Security Council Resolution 1973, UN Doc S/RES/1973 (2011), 17 Mar 2011.

46 United Nations Sanctions (Libya) Regulation 2011 (Cap 537, sub. leg. AW), originally L.N. 114 of 2011. 
Instead, China voted in favour of the first resolution and abstained when the vote was taken on the second resolution. ${ }^{47}$ Moreover, China must give specific instructions to the Chief Executive before the Hong Kong regulations can be made..$^{48}$ In March 2011, China's Ministry of Foreign Affairs instructed the Chief Executive to "fully implement" the two Security Council resolutions. ${ }^{49}$ There is no reference in either the resolutions or regulations to upholding state immunity; indeed the intention is quite clearly to the contrary. In these circumstances, the Hong Kong court could reasonably proceed on the basis that the Chinese policy was not to grant immunity to Libya and the Libyan leader for purposes of implementing the Security Council resolutions, unless there was before the court an Art 19 certificate stating otherwise.

\section{Conclusion}

The clear implication from Congo is that current and former heads of state wanted for international crimes will have full immunity in Hong Kong courts unless the immunity has been waived by the state. The property of such leaders will also be secure in Hong Kong unless immunity has been waived or the action is taken under regulations made pursuant to the United Nations Sanctions Ordinance. ${ }^{50}$ Congo exposes an irony of one country two systems, that while it entrenches strong human rights protections within Hong Kong it unfurls the welcome mat to individuals who may have committed some of the world's most egregious human rights violations.

47 See Voting Record Search from the United Nations Bibliographic Information System web site available at http://unbisnet.un.org:8080/ipac20/ipac.jsp?profile=voting\& menu= search\&submenu=power\#focus.

48 See generally Cheng Yan Ki Bonnie, "Implementing Security Council resolutions in Hong Kong: an examination of the United Nations Sanctions Ordinance" (2008) 7 Chinese Journal of International Law 65.

49 Commerce and Economic Development Bureau, "United Nations Sanctions (Libya) Regulation 2011", paper for the Legislative Council Subcommittee to Examine the Implementation in Hong Kong of Resolutions of the United Nations Security Council in relation to Sanctions, LC Paper No. CB(1)2642/10-11(01), June 2011, Annex B.

50 United Nations Sanctions Ordinance (Cap 537). 